\title{
Inhibitory activity against biological activities and antimicrobial activity against pathogenic bacteria of extracts from Hericium erinaceus
}

\author{
Myung-Uk Kim ${ }^{1} \cdot$ Eun-Ho Lee ${ }^{2} \cdot$ Hee-Young Jung ${ }^{3} \cdot$ Seung-Yeol Lee ${ }^{3} \cdot$ \\ Young-Je $\mathrm{Cho}^{2}$

\section{노루궁뎅이버섯 추출물의 생리활성 및 부패세균에 대한 항균효과}

김명욱 ${ }^{1} \cdot$ 이은호 ${ }^{2} \cdot$ 정희영 ${ }^{3} \cdot$ 이숭열 $^{3} \cdot$ 조영제 $^{2}$

Received: 28 March 2019 / Accepted: 8 May 2019 / Published Online: 30 June 2019

(C) The Korean Society for Applied Biological Chemistry 2019

\begin{abstract}
The aim of this study is to investigate the biological activities of Hericium erinaceus. 1,1-Diphenyl-2-picrylhydrazyl radical scavenging activity of $H$. erinaceus extract was higher than positive control. The inhibitory activities of xanthin oxidase, $\alpha$ glucosidase, and hyaluronidase was measured as functional food activity, and inhibitory activities on collagenase, tyrosinase, and astringent effect as beauty food activity in water and ethanol extracts from $H$. erinaceus. In functional food activity, xanthin oxidase inhibitory activities at $50-200 \mu \mathrm{g} / \mathrm{mL}$ phenolic concentration in ethanol extracts from $H$. erinaceus showed inhibitory activity in dose dependent manner. $\alpha$-Glucosidase inhibitory activities at $50 \mu \mathrm{g}$ / $\mathrm{mL}$ phenolic concentration showed high activity of higher than $80 \%$. Inhibitory activities on hyaluronidase as anti-inflammation factor showed inhibition effect in dose dependent manner both in water and ethanol extracts. In beauty food activity, Inhibitory activities on collagenase at $200 \mu \mathrm{g} / \mathrm{mL}$ phenolic concentration in
\end{abstract}

Young-Je Cho $(\bowtie)$

E-mail: yjcho@knu.ac.kr

${ }^{1}$ Gyeongbuk institute for marine bio-industry, 688-3, Hujeong-ri, Jukbyeon, Uljin, Gyeongbuk 36315, Republic of Korea

${ }^{2}$ School of Food science \& Biotechnology, Kyungpook National University, 80 University Street, Bukgu, Daegu 41566, Republic of Korea

${ }^{3}$ School of Applied Biosciences, Kyungpook National University, 80 University Street, Bukgu, Daegu 41566, Republic of Korea

This is an Open Access article distributed under the terms of the Creative Commons Attribution Non-Commercial License (http://creativecommons. org/licenses/by-nc/3.0/) which permits unrestricted non-commercial use, distribution, and reproduction in any medium, provided the original work is properly cited. water and ethanol extracts showed high activity to 65.09 and $58.38 \%$ dose dependently. Tyrosinase inhibitory activity in water extract showed 9.4-58.24\%. Astringent activity as pore shrink effect in ethanol extracts also showed a very high activity of 18.94-100\%. Antimicrobial activity on pathogenic bacteria was highly effective on Staphylococcus aureus, Salmonella enteritidis, Vibrio parahaemolyticus and Escherichia coli at $2.5 \mathrm{mg} / \mathrm{mL}$ or above. Therefore, the extracts from $H$. erinaceus can be used as a functional food and beauty food resources and natural antimicrobial agent on pathogenic bacteria in food.

Keywords Antimicrobial activity $\cdot$ Biological enzyme $\cdot$ Hericium rinaceus $\cdot$ Inhibition $\cdot$ Pathogenic bacteria

\section{서 론}

국민소득 증가와 더불어 건강에 대한 관심이 고조되면서 약용 식품자원 등 친환경 기능성제품에 대한 수요가 증가하는 방향 으로 식패턴이 변화되고 있다[1]. 한편, 건강에 대한 관심은 식 패턴 뿐만 아니라 예방의학 및 질병 치료에도 영향을 주어 인 체의 조절기능이 있는 기능성 식품에 대한 수요가 급격히 증가 하고 있으며, 따라서 식품산업에 있어 기능성 식품 분야가 차 지하는 비중이 급격히 증가하고 있는 추세이고 앞으로의 발전 가능성이 무한하다고 할 수 있겠다. 현재 건강관련 식품소재의 연간 수입액이 1600 억원에 달하는 실정에서 천연 자원의 특성 을 최대한 부각시킨 기능성소재 및 식품이 개발된다면 원료의 효율적 이용과 경제성이 높아질 것으로 기대된다[2-4]. 이와같 은 사회적 경향에 맞추어 식품소비자들이 건강에 대한 관심이 
증가됨으로 인해 한국농촌경제연구원 등에서 약용자원으로 분 류되는 버섯에 대한 소비 및 활용 의향이 확대될 것으로 전망 하고 있으며, 그중 노루궁뎅이버섯의 경우 그 기능성이 밝혀지 기 시작함에 따라 소비량이 늘어나게 되었으나 민간에서도 단 순가공의 차로 섭취하는 등 가공방법 등을 포함한 다양한 연구 가 미흡한 실정으로 원료에 적합한 공정과 기술의 적용이 필요 하게 되었다[5-10].

노루궁뎅이버섯은 학명은 Hericium erinaceum이며, 담자균류, 민주름버섯목(Aphyllophorales), 턱수염버섯과(Hydnaceae), 산호 침버섯속(Hericium)에 속한다[11]. 분포지역으로는 한국을 비롯 하여, 동아시아, 유럽, 북미에 분포하고 있으며, 최근 국내에서 도 인공재배가 되고 있는 버섯이다. 노루궁뎅이버섯의 영양학적 성분은 당질과 단백질을 주성분으로 하고, 무기질이 많으며, 지 방함량이 적다[12-14]. 노루궁뎅이버섯은 오래 전부터 식용 및 약용으로 이용되어 왔으며 가을철 활엽수의 고목이나 생목에서 발생하는 버섯으로 중국에는 후두버섯이라고 칭하고 있다. 노루 궁뎅이버섯의 약리작용으로는 항암 및 면역기능을 증강시키며 만성위염, 신체허약 등에 효능이 있다고 알려지고 있으며, 노루 궁뎅이버섯의 항암효과를 가진 성분을 포함하여 여러 다양한 생 리활성 물질을 함유하고 있는 것으로 보고되고 있다[15]. 그 이 외에 항종양예방, 면역력증강, 생체항상성, 항균작용, 신체리듬 의 조절, 질병회복, 콜레스테롤 저하, 노인성질병개선, 항혈전, 혈압강하, 혈당강하 등, 많은 기능성을 함유하고 있다고 보고 되어왔고 중국에서는 식용뿐만 아닌 약용으로도 많이 이용한다 고 보고하였다[16,17]. 또한 식품의 산화를 방지하기 위하여 지 금까지 수많은 항산화 물질들이 개발되고 이용되어 왔는데, 합 성 항산화제인 BHT 등은 가격이 저렴하고 우수한 항산화력을 나타내는 반면 과잉 섭취 시 독성이 우려되어 사용이 기피되고 있기 때문에 화학적 합성 첨가물에 대한 일반인들의 안전성에 대한 우려가 높아지고 있어 우수한 항산화 활성을 가지는 천연 물을 이용하여 항산화제 개발에 대한 연구에 집중되고 있어[18], 버섯에 함유되어 있는 항산화 성분도 천연항산화제로의 개발을 위한 우수한 자원으로 활용될 수 있다.

본 연구에서는 노루궁뎅이버섯의 추출물을 제조한 후 총 페 놀성 성분의 함량 및 항산화, 항당뇨, 항염증 및 통풍억제 등의 건강기능성 식품활성과 미백, 주름개선 및 모공축소 효과 등의 화장품 활성 등을 검토하고, 식품부패유발미생물에 대한 항균활 성을 측정하여 기능성 식품 소재를 개발하기 위한 기초자료로 활용하고자 하였다.

\section{재료 및 방법}

\section{재료}

본 실험에 사용된 노루궁뎅이버섯은 경북 울진군 $\mathrm{K}$ 표고버섯 농장에서 제공 받아 동결건조한 후 분쇄기로 분말화하여 -70 ${ }^{\circ} \mathrm{C}$ deep freezer에 보관하면서 실험에 사용하였다.

\section{추출물의 제조}

노루궁뎅이버섯 분쇄시료 $100 \mathrm{~g}$ 에 10 배의 물 또는 $60 \%$ ethanol 을 가한 후 24 시간 동안 2회 반복 추출하였다. 각 추출물은 여 과지(Whatman No. 3, Maidstone, England)로 여과한 후 회전
진공농축기로 농축하고, 각 농축물은 동결건조하여 분말화 시킨 후 추출동결건조물로 사용하였으며, 페놀성 성분 시료는 노루궁 뎅이 버섯 추출물에 함유된 페놀성 성분의 함량를 측정 후, 50 $200 \mu \mathrm{g} / \mathrm{mL}$ 의 농도로 조절하여 실험에 이용하였다.

\section{총 페놀성 성분 함량 측정}

총 페놀성 성분 정량은 Folin과 Denis의 방법[19]에 준하여 추 출물 $1 \mathrm{~mL}$ 에 $95 \%$ ethanol $1 \mathrm{~mL}$ 와 증류수 $5 \mathrm{~mL}$ 를 첨가하고 $1 \mathrm{~N}$ Folin-ciocalteu reagent $0.5 \mathrm{~mL}$ 를 잘 섞어 5 분간 방치한 후 $\mathrm{Na}_{2} \mathrm{CO}_{3} 1 \mathrm{~mL}$ 를 가하여 $725 \mathrm{~nm}$ 에서 흡광도를 1 시간 이내에 측정하여 gallic acid를 이용한 표준곡선으로부터 양을 환산하 였다.

\section{항산화효과 측정(DPPH radical 소거활성)}

1,1-Diphenyl-2-picrylhydrazyl (DPPH) radical에 대한 소거활성 은 Blois의 방법[20]에 준하여 측정하였다. 반응구는 노루궁뎅 이버섯으로부터 추출한 페놀성 성분 함량을 $50-200 \mu \mathrm{g} / \mathrm{mL}$ 의 농 도로 조절하여 실험에 이용하였다. 즉, 각 시료 $1 \mathrm{~mL}$ 에 $60 \mu \mathrm{M}$ $\mathrm{DPPH} 3 \mathrm{~mL}$ 를 넣고 vortex한 후 실온에서 15 분 동안 반응시킨 다음 $517 \mathrm{~nm}$ 에서 흡광도를 측정하여 $\mathrm{DPPH}$ radical 소거활성은 시료 용액의 반응구와 대조구의 흡광도 차이로 계산하여 나타 내었다.

\section{Xanthine oxidase (XOase) 저해효과}

XOase 저해효과는 Stirpe와 Corte의 방법[21]에 준하여, $0.1 \mathrm{M}$ potassium phosphate buffer $(\mathrm{pH}$ 7.5)에 녹인 기질액 $2 \mathrm{mM}$ xanthine $3 \mathrm{~mL}$ 에 효소 $(0.05 \mathrm{U} / 0.1 \mathrm{~mL}) 0.1 \mathrm{~mL}$ 와 시료 $0.3 \mathrm{~mL}$ 를 넣고 대조구에는 시료 대신 증류수를 $0.3 \mathrm{~mL}$ 첨가하여 $37^{\circ} \mathrm{C}$ 에 서 5 분간 반응시키고 종료시약으로 $20 \% \mathrm{TCA} 1 \mathrm{~mL}$ 를 가한 후 반응액을 원심분리하여 단백질을 제거하고, 생성된 uric acid를 흡광도 $292 \mathrm{~nm}$ 에서 측정하였다.

\section{$\alpha$-Glucosidase 저해효과}

$\alpha$-Glucosidase 저해효과는 Tibbot과 Skadsen의 방법[22]에 준하 여, $50 \mathrm{mM}$ sodium succinate buffer $(\mathrm{pH}$ 6.8)에 $\rho$-nitrophenol$\alpha$-D-glucopyranoside (PNPG)를 용해시켜 $1 \mathrm{mg} / \mathrm{mL}$ 의 농도로 기 질을 만들고, 기질 $1 \mathrm{~mL}$ 와 효소액 $0.1 \mathrm{~mL}$ 를 혼합하고 대조구에 는 증류수 $0.1 \mathrm{~mL}$, 반응구에는 $200 \mu \mathrm{g} / \mathrm{mL}$ 농도의 시료 $0.1 \mathrm{~mL}$ 를 넣어 $37^{\circ} \mathrm{C}$ 에서 30 분간 반응시킨 후 $1 \mathrm{~N} \mathrm{NaOH} 0.1 \mathrm{~mL}$ 를 첨가하여 발색시켜 $400 \mathrm{~nm}$ 에서 흡광도를 측정하였다.

\section{Hyaluronidase (HAase) 저해효과}

HAase 저해효과는 Dorfman와 Ott의 방법[23]에 준하여, sodiumhyaluronic acid (HA)로부터 형성된 N-acetyl-glucosamine을 glucoxazoline 유도체로 변형시킨 후 $\rho$-dimethylaminobenzaldehyde로 발색시켜 흡광도 $600 \mathrm{~nm}$ 에서 측정하였다.

\section{Collagenase 저해효과}

Collagenase 저해효과는 Wunsch와 Heidrich의 방법[24]에 준하 여, $0.1 \mathrm{M}$ Tris- $\mathrm{HCl}$ buffer $(\mathrm{pH} 7.5)$ 에 $4 \mathrm{mM} \mathrm{CaCl} 2$ 를 첨가하 여 4-phenylazobenzyloxycarbonyl-Pro-Leu-Gly-Pro-D-Arg ( $0.3 \mathrm{mg}$ / $\mathrm{mL}$ )를 녹인 기질액 $0.25 \mathrm{~mL}$ 와 $50-200 \mu \mathrm{g} / \mathrm{mL}$ phenolic compounds 
농도의 각 시료 용액 $0.1 \mathrm{~mL}$ 의 혼합액에 $0.2 \mathrm{mg} / \mathrm{mL}$ collagenase (Sigma-Aldrich Co. St. Louis, MO, USA) $0.15 \mathrm{~mL}$ 를 첨가하 여 실온에서 20 분간 방치한 후 $6 \%$ citric acid $0.5 \mathrm{~mL}$ 를 넣어 반응을 정지시킨 다음, ethyl acetate $2 \mathrm{~mL}$ 를 첨가하고 $320 \mathrm{~nm}$ 에서 흡광도를 측정하였다.

\section{Tyrosinase 저해효과}

Tyrosinase 저해효과는 Hearing의 방법[25]에 준하여, $0.1 \mathrm{M}$ sodium phosphate buffer (pH 6.8) $2.3 \mathrm{~mL}$ 와 기질액 $1.5 \mathrm{mM}$ L-tyrosine 용액 $0.4 \mathrm{~mL}$ 의 혼합액에 $250 \mathrm{U} / \mathrm{mL}$ mushroom tyrosinase (Sigma-Aldrich Co.) $0.1 \mathrm{~mL}$ 와 $50-200 \mu \mathrm{g} / \mathrm{mL}$ 페놀 성 성분 농도의 각각의 시료 $0.2 \mathrm{~mL}$ 를 넣고 대조구에는 시료 대신 증류수를 $0.2 \mathrm{~mL}$ 를 첨가하여 $37^{\circ} \mathrm{C}$ 에서 20 분간 반응시킨 다음, $475 \mathrm{~nm}$ 에서 흡광도를 측정하였다.

\section{Astringent 효과}

Astringent 활성측정은 Lee 등[26]의 방법에 따라 측정하였다. 피부 단백질과 유사한 혈액 단백질(hemoglobin)을 사용하여, 원 심분리관 용기에 각각의 시료용액과 헤모글로빈 용액(SigmaAldrich Co, Louis, MO, USA)을 1:1로 넣어서 진탕 혼합한 다음 $1,500 \mathrm{rpm}$ 에서 3 분간 원심분리 후 $576 \mathrm{~nm}$ 에서 흡광도를 측정하였다. Astringent 활성은 (1-시료첨가군의 흡광도/대조구 의 흡광도 $) \times 100$ 으로 나타내었다.

\section{항균활성 측정}

항균활성 측정용 균주는 Listeria monocytogenes KCTC 3569, Staphylococcus aureus KCCM 12255, Pseudomonas fluorescens ATCC 21541, Baciilus cereus ATCC 21366, Bacillus megaterium ATCC 14581, Escherichia coli ATCC 11775, Salmonella enteritidis KCTC 12400, Vibrio parahaemolyticus ATCC 17802 를 사용하였으며, 분리균주의 항균활성은 paper disc method에 의한 clear zone의 생성 유무로 측정하였다[27].

\section{통계처리}

실험 결과는 3 번 이상 반복하여 측정한 후 평균값으로 나타내 었으며, 실험결과의 통계분석은 SAS (Statistical Analysis System, SAS Institute Inc., Cary, NC, USA)의 Duncan's multiple range test를 이용하여 평균값간의 유의성 검정 $(p<0.05)$ 을 하였다.

\section{결과 및 고찰}

\section{노루궁뎅이버섯 추출물의 총 페놀성 성분 함량 측정}

식물성 식품 속에 함유되어 있는 많은 생리활성 물질 중 폴리 페놀 물질이 가장 많이 함유되어 있으며, 또한 높은 항산화 활 성을 가지는 것으로 알려져 있고, 플라보노이드는 식물에 의해 합성된 페놀성 성분의 가장 큰 부류이며, 효과적인 free radical scavenger로서 항산화 효과를 가진다[28]. 노루궁뎅이버섯 추출 물의 총 페놀성 성분 함량을 측정한 결과는 Table 1 에서와 같 이 물 추출물은 $0.349 \pm 0.004 \mathrm{mg} / \mathrm{sample} \mathrm{g}$ 이었고, 에탄올 추출물 은 $0.258 \pm 0.012 \mathrm{mg} / \mathrm{sample} \mathrm{g}$ 을 나타내었다.
Table 1 Comparison of total phenolic contents in extract from Hericium erinaceum

\begin{tabular}{|c|c|c|}
\hline \multirow{2}{*}{ Sample } & \multicolumn{2}{|c|}{ Total phenolic content (mg/sample g) } \\
\hline & Water extract & Ethanol extract \\
\hline Hericium erinaceum & $0.349 \pm 0.004^{1)}$ & $0.258 \pm 0.012$ \\
\hline
\end{tabular}

\section{노루궁뎅이버섯 추출물의 추출동결건조물과 노루궁뎅이버섯에 함유된 페놀성 성분의 생리활성 비교}

노루궁뎅이 버섯의 추출동결건조물과 페놀성 성분의 생리활성 효능을 비교를 위해 DPPH radical을 측정한 결과 Fig. 1에서와 같이 노루궁뎅이 버섯 water, ethanol 추출물의 $150 \mu \mathrm{g} / \mathrm{mL}$ 농도 의 추출동결건조물에서는 각각 $3.32,4.54 \%$ 의 $\mathrm{DPPH}$ radical 소 거활성을 나타내었으나, $150 \mu \mathrm{g} / \mathrm{mL}$ 페놀성 성분 농도에서 각각 69.44, 91.34\%의 DPPH radical 소거활성을 나타내어 노루궁뎅 이버섯의 생리활성은 버섯에 함유된 페놀성 성분에 의해 활성 이 지배되는 것으로 확인되었다. 따라서 노루궁뎅이버섯의 페놀 성 성분이 생리활성에 직접적으로 관여한다고 판단되어, 노루궁 뎅이버섯의 페놀성 성분을 기준으로 기능성 화장품활성 및 건 강기능성 식품활성을 검토하였다.

\section{노루궁뎅이버섯 추출물의 항산화효과}

항산화물질은 세포내에서 free radical이 DNA를 공격하거나, 지 질을 산화시키기 전에 그들을 중화시켜 식품의 변질을 방지하 고 인체에서의 노화 방지, 성인병 예방 등의 기능을 할 수 있 는 물질로 알려져 있으며[29]. 체내 유해물질과 반응하여 활성 산소에 의한 연쇄반응을 막아 주어 세포를 보호하는 역할을 수 행한다[30]. 노루궁뎅이버섯의 항산화력은 페놀성 성분 농도 기 준으로 측정하였으며, 실험은 $50-200 \mu \mathrm{g} / \mathrm{mL}$ 페놀성 성분 농도 범위에서 $\mathrm{DPPH}$ radical 소거활성을 측정한 결과 Fig. 2에서와 같이 노루궁뎅이버섯은 농도 의존적으로 $\mathrm{DPPH}$ radical 소거활 성이 있는 것으로 나타났으며, positive control로 사용한 BHT 보다 더 높은 항산화력을 나타내었다. 따라서 노루궁뎅이버섯 추출물은 높은 항산화 활성을 가짐으로 인해 항노화를 위한 기 능성 소재로 활용이 가능할 것으로 판단되었다.

\section{노루궁뎅이버섯 추출물의 XOase 저해효과}

통풍은 대표적인 대사질환 중 하나로 미국에서는 가장 흔한 염 증성 관절염으로 알려져 있으며, 퓨린 대사의 최종산물인 요산 (uric acid)이 몸 밖으로 빠져나가지 못하고 혈액을 통해 관절에 축적되어 염증성 질환인 관절염과 통증을 동반하는 질환이다 [31]. XOase는 purine 대사에 관여하는 효소로 xanthine 또는 hypoxanthine으로부터 요산을 생성시키는 것으로 알려져 있다. 노루궁뎅이버섯의 통풍 억제효과 확인을 위해 XOase 저해효과 를 페놀성 성분 농도 기준으로 측정한 결과는 Fig. 3-A에서와 같이 노루궁뎅이버섯 ethanol 추출물 $50-200 \mu \mathrm{g} / \mathrm{mL}$ 페놀성 성 분 농도구간에서 농도의존적으로 $28.1-100 \%$ 의 매우 높은 XOase 저해효과를 나타내었으며, 통풍치료제로 알려진 대조구 allopurinol보다 더 우수한 XOase 저해효과를 나타내었다. 물 추 출물에서 XOase 저해효과가 나타나지 않은 것은 각 추출물에 


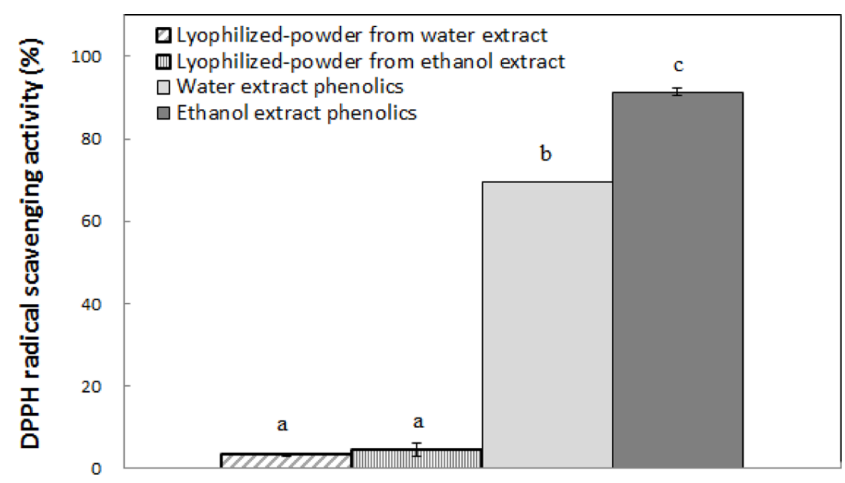

Concentration $(150 \mu \mathrm{g} / \mathrm{mL})$

Fig. 1 The antioxidant activity of the lyophilized-powder from extracts and the phenolics from Hericium erinaceum. Values are mean $\pm \mathrm{SD}$ of triplicate determinations. Means with different letters (a-c) above the bars are significantly different at $p<0.05$ by Duncan's multiple-range test

함유되어 있는 페놀성 성분의 profile이 다르기 때문으로 추측 하였고[32], 향후 이와 관련된 연구가 진행되어야 할 것으로 사 료되었다. 따라서 통풍 및 관절염 개선 효능을 기대할 수 있을 것으로 판단되었다.

\section{노루궁뎅이버섯 추출물의 $\alpha$-glucosidase 저해효과}

$\alpha$-Glucosidase는 소장의 brush-border membrane에 존재하는 소 화효소로서 이당류나 다당류 형태의 탄수화물이 소화 흡수되기 위한 상태인 단당류로 가수분해하는 역할을 한다[33]. $\alpha$ Glucosidase 저해제는 탄수화물이 소화되는 과정에서 polysacchorided의 $\alpha$-결합의 분해를 저해함으로 $\alpha$-glucose의 생성을 억 제하여 혈당상승 조절을 통해 당뇨병에 도움을 줄 수 있다고 알려져 있다[34]. 노루궁뎅이버섯이 당뇨 억제효과를 나타내는 지 확인하기 위해 $\alpha$-glucosidase 저해활성을 페놀성 성분 농도 기준으로 측정한 결과, Fig. 3-B에서와 같이 노루궁뎅이버섯 ethanol 추출물 $50 \mu \mathrm{g} / \mathrm{mL}$ 페놀성 성분 농도에서 $82.8 \%$ 의 매우 높은 저해효과를 나타내었으며, $\alpha$-glucosidase 저해효과로 인해 Type-2의 항당뇨에 효능이 있을 것으로 판단되었다. 물 추출물 에서 $\alpha$-glucosidase 저해효과가 나타나지 않은 것은 각 추출물 에 함유되어 있는 페놀성 성분의 profile이 다르기 때문으로 추 측하였고[32], 향후 이와 관련된 연구도 진행되어야 할 것으로 판단되었다.

\section{노루궁뎅이버섯 추출물의 HAase 저해효과}

염증반응은 외부자극에 대한 생체조직의 방어반응의 하나로서 활성화된 면역세포에 의해 일어나는 일련의 면역반응이다. 염증 형성의 중요 요소인 macrophage의 phagocytic ability는 고분자 다당인 $\mathrm{HA}$ 에 의해 저해되지만, 저분자 $\mathrm{HA}$ 는 inflammation, fibrosism collagen deposition을 증가시키는 것으로 알려져 있다 [35]. 따라서 HA 분해효소인 HAase의 활성을 억제함으로서 HA 의 고분자 형태를 유지시켜 항염증 효과를 기대할 수 있다. 항 염증 효과 확인을 위해 HAase 저해활성을 페놀성 성분 농도 기준으로 측정한 결과는 Fig. 3-C에서와 같이 노루궁뎅이버섯 물 추출물의 $50-200 \mu \mathrm{g} / \mathrm{mL}$ 페놀성 성분 전 농도구간에서 19.8-

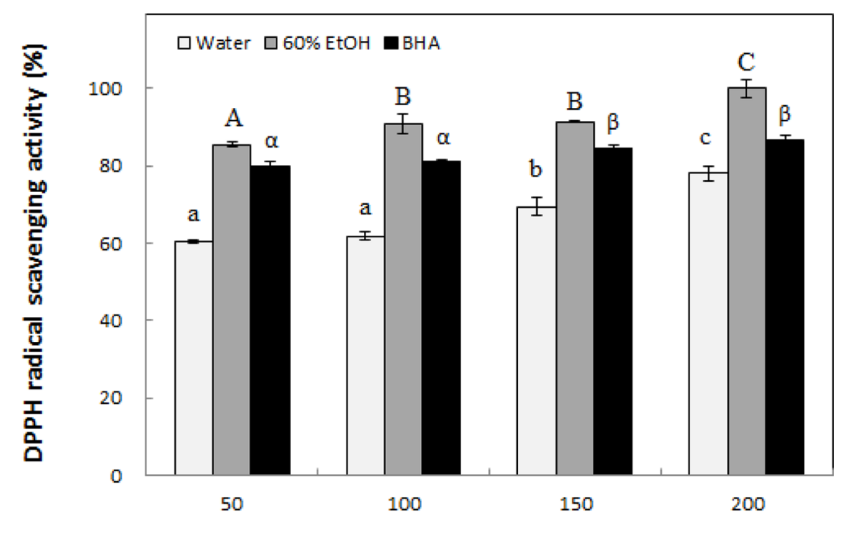

Phenolic content $(\mu \mathrm{g} / \mathrm{mL})$

Fig. 2 The DPPH radical scavenge activity of the water and the ethanol extracts from Hericium erinaceum. Values are mean $\pm \mathrm{SD}$ of triplicate determinations. Means with different letters (a-c), (A-C), $(\alpha-\delta)$ above the bars are significantly different at $p<0.05$ by Duncan's multiple-range test

$47.3 \%$ 의 저해효과를 나타내었고, ethanol 추출물 역시 전 농도 구간에서 25.0-60.3\%의 HAase 저해효과를 나타내었다. 따라서 노루궁뎅이버섯은 우수한 항염증 효능을 나타내는 것이 확인되 었다.

\section{노루궁뎅이버섯 추출물의 collagenase 저해효과}

피부의 섬유아세포에서 생성되는 collagen은 세포 외 기질 (extracellular matrix)의 주요 구성성분으로 견고한 3중 나선구 조를 가지고 있는 단백질로 피부, 건(tendon), 뼈 및 치아의 유 기 물질의 대부분을 형성한다. 이러한 collagen은 자외선 조사 에 의한 광노화와 collagenase에 의한 분해에 의해 감소하게 되 고, collagen의 감소는 피부의 주름 형성과 밀접한 연관이 있다 [36]. 주름개선 효과를 확인하기 위해 collagenase 저해활성을 페 놀성 성분 농도 기준으로 측정한 결과 Fig. $4 \mathrm{~A}$ 에서와 같이 노 루궁뎅이버섯 $50-200 \mu \mathrm{g} / \mathrm{mL}$ 페놀성 성분 농도구간에서 물 추 출물이 $13.7-65.1 \%$, ethanol 추출물이 $4.9-58.3 \%$ 의 collagenase 저해 효과를 나타내었다. 시중에 판매되는 기능성 화장품에 주 름개선제로 사용되고 있는 collagenase 저해물질로 알려진 epigallocatechin-gallate (EGCG)에 비해 효능이 다소 낮은 결과 를 나타내었으나, 처리 용량을 높인다면 $\mathrm{EGCG}$ 에 필적하는 효 과를 나타낼 수 있을 것이라 판단되었다.

\section{노루궁뎅이버섯 추출물의 tyrosinase 저해효과}

Tyrosinase는 L-tyrosine에 작용하여 3,4-dihydroxy phenylalanine 를 거쳐 L-dopaquinone으로 전환되면서 최종적으로 멜라닌 형 성에 관여하는 pathway에서 반응을 촉진하는 key enzyme으로 작용한다[37,38]. 따라서 tyrosinase는 melanin 생합성 과정의 핵 심 효소로 tyrosinase 저해제는 피부의 melanin 색소 생성을 조 절할 수 있는 물질로 사용할 수 있다. 따라서 미백효과 확인을 위해 노루궁뎅이버섯 추출물의 tyrosinase 저해활성을 페놀성 성 분 농도 기준으로 측정한 결과, Fig. 4-B에서와 같이 노루궁뎅 이버섯 $50-200 \mu \mathrm{g} / \mathrm{mL}$ 페놀성 성분 농도구간에서 물 추출물이 8.9-58.2\%의 저해효과를 ethanol 추출물이 9.4-16.8\%의 tyrosinase 

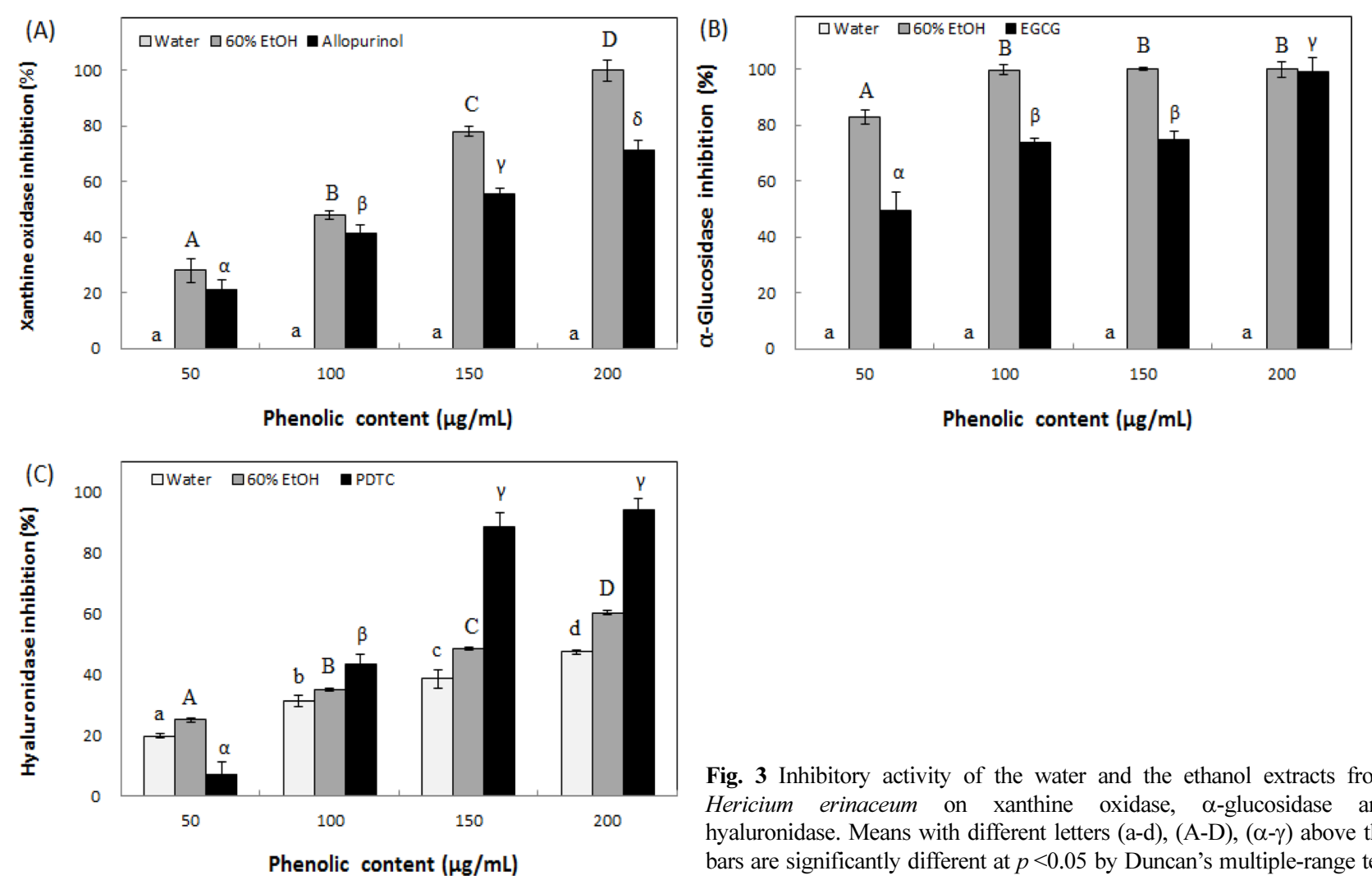

Fig. 3 Inhibitory activity of the water and the ethanol extracts from Hericium erinaceum on xanthine oxidase, $\alpha$-glucosidase and hyaluronidase. Means with different letters (a-d), (A-D), $(\alpha-\gamma)$ above the bars are significantly different at $p<0.05$ by Duncan's multiple-range test
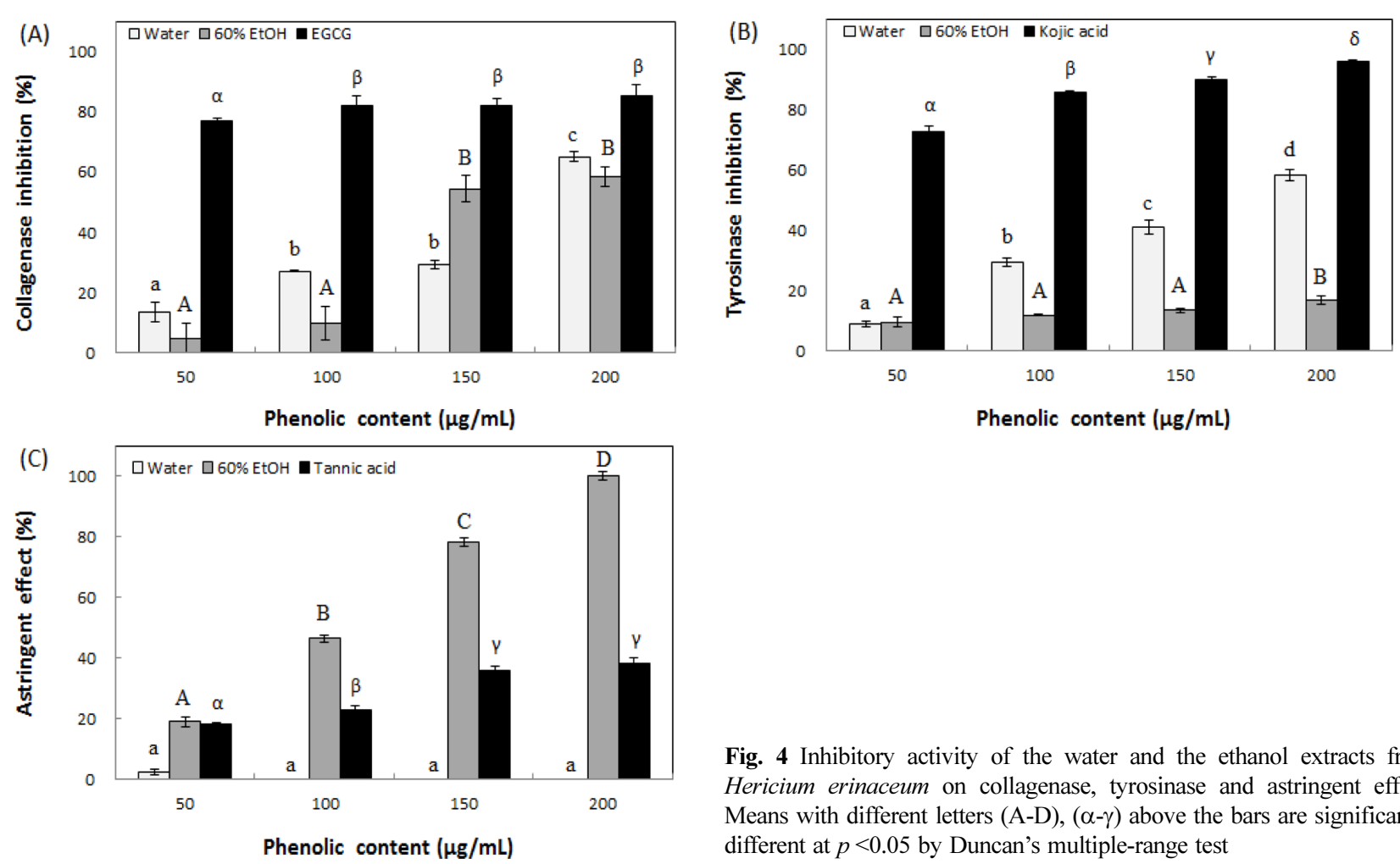

Fig. 4 Inhibitory activity of the water and the ethanol extracts from Hericium erinaceum on collagenase, tyrosinase and astringent effect. Means with different letters (A-D), $(\alpha-\gamma)$ above the bars are significantly different at $p<0.05$ by Duncan's multiple-range test 
Table 2 Antibacterial activity of ethanol extracts from Hericium erinaceum against pathogenic bacteria

\begin{tabular}{ccccccccccccc}
\hline \hline \multirow{2}{*}{ Sample $^{1)}$} & $\begin{array}{c}\text { Phenolic concentration } \\
\text { (mg/mL) }\end{array}$ & A & B & C & D & E & F & G & H \\
\hline & 1 & -2 & - & - & - & - & - & + & - \\
Hericium & 2.5 & - & + & - & - & - & + & + & + \\
erinaceum & 5 & + & + & - & - & + & + & + & + \\
& 10 & + & + & - & - & + & + & + & + \\
\hline
\end{tabular}

${ }^{1)}$ A: Listeria monocytogenes, B: Staphylococcus aureus, C: Bacillus cereus, D: Bacillus megaterium, E: Pseudomonas fluorescens, F: Salmonella enteritidis, G: Vibrio parahaemolyticus, H: Escherichia coli

${ }^{2)}+$ : positive, -: negative

저해효과를 나타내었다. 이러한 결과는 노루궁뎅이버섯 추출물 이 미백효과를 나타내는 기능성 화장품 원료로 사용이 가능하 다는 결과를 제시하는 것으로 미용산업에 적용하기 위한 자료 로 활용이 가능할 것으로 판단되었다.

\section{노루궁뎅이버섯 추출물의 astringent 효과}

수렴효과는 피부 단백질이 고분자 페놀성 물질과 결합하여 가 교결합을 형성하여 피부가 수축되는 현상으로 수렴제는 피부와 점막 혈관 등을 수축시키는 작용이 있고, 세포간극 및 림프간 극을 가로막아 점액의 분비를 억제시키는 효과가 있어 피부의 모공을 수축하게 된다[39]. 모공 수축 효과를 확인하기 위해 astringent 효과를 페놀성 성분 농도 기준으로 측정한 결과 Fig. 4-C에서와 같이 노루궁뎅이버섯 ethanol 추출물 $50-200 \mu \mathrm{g} / \mathrm{mL}$ 페놀성 성분 농도구간에서 $18.9-100.0 \%$ 의 농도의존적인 수렴효 과를 나타내었으며, 수렴제로 잘 알려진 대조구 tannic acid 보 다 우수한 매우 높은 효능을 보여주었다. 따라서 노루궁뎅이버 섯 ethanol 추출물의 우수한 모공수축 효과에 의한 피부 정돈효 과 및 머리 모공축소 효과에 의한 탈모 방지 효능도 기대할 수 있었다.

\section{노루궁뎅이버섯 추출물의 식품부패유발미생물에 대한 항균활성} 노루궁뎅이버섯 에탄올추출물의 식품부패유발미생물에 대한 항 균활성을 페놀성 성분 농도 기준으로 측정한 결과는 Table 2에 서와 같이 노루궁뎅이버섯 에탄올추출물은 Vibrio parahaemolyticus 에 대해서는 $1.0 \mathrm{mg} / \mathrm{mL}$ 의 농도에서, Staphylococcus aureus, Salmonella enteritidis 및 Escherichia coli에 대해서는 $2.5 \mathrm{mg}$ / $\mathrm{mL}$ 의 농도에서, Listeria monocytogenes와 Pseudomonas fluorescens 에 대해서는 $5.0 \mathrm{mg} / \mathrm{mL}$ 의 농도에서 항균활성을 나타내었다. 또 한 Bacillus cereus, Bacillus megaterium 등에 대해서는 항균효 과를 나타내지 않았다. 이러한 결과로 노루궁뎅이버섯 추출물은 식품부패유발미생물에 대해 우수한 항균활성을 나타냄에 따라 천연 방부제로 활용이 가능하리라 판단되었다.

\section{초 록}

노루궁뎅이버섯(Hericium erinaceum) 추출물의 총 페놀성 성분 함량은 물 추출물은 $0.349 \pm 0.004 \mathrm{mg} / \mathrm{sample} \mathrm{g}$ 이었고, 에탄올 추 출물은 $0.258 \pm 0.012 \mathrm{mg} / \mathrm{sample} \mathrm{g}$ 을 나타내었다. 노루궁뎅이버섯 은 농도 의존적으로 $\mathrm{DPPH}$ 라디칼 소거활성이 있는 것으로 나 타났으며, positive control로 사용한 BHA 보다 더 높은 항산화
력을 나타내었다. 기능성식품활성에서 노루궁뎅이버섯 에탄올추 출물은 $50-200 \mu \mathrm{g} / \mathrm{mL}$ 페놀성 성분 농도구간에서 농도 의존적 으로 xanthine oxidase 저해효과를 나타내었으며, $\alpha$-glucosidase 저해 활성은 $50 \mu \mathrm{g} / \mathrm{mL}$ 페놀성 성분 농도에서 $80 \%$ 이상의 높 은 저해활성을 나타내었다. 항염증인자로 hyaluronidase 저해활 성은 물과 에탄올 추출물 모두 농도의존적으로 저해효과를 나 타내었다. 기능성 미용식품활성에서 노루궁뎅이버섯 에탄올추출 물의 collagenase 저해활성은 $200 \mu \mathrm{g} / \mathrm{mL}$ 페놀성 성분 농도에서 물과 에탄올 추출물에서 각각 $65.09 \%$ 와 $58.38 \%$ 의 높은 저해활 성을 나타내었고, tyrosinase 저해활성을 측정한 결과, 물 추출 물에서 9.4-58.24\%의 농도의존적인 저해효과를 나타내었다. 또 한 노루궁뎅이버섯 ethanol 추출물 $50-200 \mu \mathrm{g} / \mathrm{mL}$ 페놀성 성분 농도구간에서 18.94-100\%의 우수한 모공수축 효과가 확인되었 다. 식품부패유발미생물에 대한 항균활성을 측정한 결과, 노루 궁뎅이버섯 추출물은 $2.5 \mathrm{mg} / \mathrm{mL}$ 이상의 농도에서 Staphylococcus aureus, Salmonella enteritidis, Vibrio parahaemolyticus 및 Escherichia coli에 대한 높은 항균활성을 나타내었다. 따라서 노 루궁뎅이버섯은 건강기능성 식품 및 미용식품원료로 활용이 가 능하며 부패균에 대한 천연방부제로 활용이 가능할 것으로 판 단되었다.

Keywords 노루궁뎅이버섯 - 부패균 - 생리활성효소 - 억제효과 항균효과

\section{References}

1. Huang MT, Ho CT, Lee CY (1992) Phenolic compounds in food and their effects on health. ACS publisher, p.48-52, Washington, DC, USA

2. Kim JS, Oh CH, Jeon H, Lee KS, Ma SY (2002) Immunoregulatory property of fruit-extracts of Cornus kousa Burg. Kor J Med Crop Sci 10: 327-332

3. Kim KB, Jo BS, Park HJ, Park KT, An BJ, Ahn DH, Kim MU, Chae JW, Cho YJ (2012) Healthy functional food properties of phenolic compounds isolated from Ulmus pumilia. Kor J Food Preserv 19: 909 918

4. Son CY, Beak IH, Song GY, Kang JS, Kwon KI (2009) Pharmacological effect of decursin and decursinol angelate from Angelica gigas Nakai. Yakhak Hoeji 53: 303-313

5. Choi JH, HA TM, Kim YH, Rho YD (1996) Studies on the main factors affecting the mycelial growth of Phellinus lintenus. Kor J Mycol 24: 214-222

6. Tsukagoshi S, Ohashi F (1974) Protein-bound polysaccharide preparation, PS-K, effective against mouse sarcoma-180 and rat ascites 
hepatoma AH-13 by oral use. Gann 65: $557-558$

7. Kang MG, Bolormaa Z, Lee JS, Seo GS, Lee JS (2011) Antihypertensive activity and anti-gout activity of mushroom Sarcodon aspratus. Kor J Mycol 39: 53-56

8. Hyun KW, Jeong SC, Lee DH, Park JS, Lee JS (2006) Isolation and characteriaztion of a noble platelet aggregation inhibitory peptide from the medicinal mushroom, Inonotus obliquus. Peptides 27: 1173-1178

9. Shin HH, Choi HS (1998) Purification and partial characterization of a metalloprotease in Flammulina velutipes. J Micrbiol 36: 20-25

10. Kim JH, Kim YS (2001) Characterization of a metalloenzyme from a wild mushroom, Tricholoma saponaceum. Biosci Biotech Biochem 65: 356-362

11. Kawagishi T, Shimada A, Hosokawa S, Mori H, Okamoto K, Sakamoto H, Ishiguro Y, Sakemi S, Bordner J, Kojima N, Furukawa S (1996) Erinacines E, F and G, stimulatores of verve growth factor (NGF)synthesis, from the mycelia of Hericum erinaceus. Tetrahedron Lett 37: 7399-7402

12. Park WH, Lee HD (1999) An illustrated guide book of colorful Korean medicinal mushroom, p. 442-443, Gyohaksa, Korea

13. Yearul KA, Shuichi K (1989) Dietary mushroom reduce blood pressure in spontaneously hypertensive rat. J Nutr Sci Vitaminol 35: 91-96

14. Yanmaguchi M, Yearul KA (1987) Effect of shitake and maitake mushroom on blood pressure and plasm lipids of spontaneously hypertensive rats. J Nutr Sci Vitaminol 33: 341-345

15. Mizuno T, Wasa T, Ito H, Suzuki C, Ukai N (1992) Antitumor active polysaccharides isolated from the fruiting body of Hericum erinaceus: an edible and medicinal mushroom called Yamabushitake or Houtou. Biosci Biotech Biochem 56: 347-348

16. Ryu SR, Lee WY, Ka KH (2009) Comparative study on the sawdust cultivation and the antioxidant of Hericum spp. Kor J Mycol 37: 80-85

17. Kawagishi H, Shimada A, Hosokawa S, Mori H, Sakamoto H, Ishiguro Y, Sakemi S, Bordner J, Kojima N, Furukawa S (1996) Erinacines E, F and $\mathrm{G}$ stimulator of nerve growth factor (NGF)-synthesis from the mycelia of Hericum erinaceus. Tetrahedon Letters 37: 7399-7402

18. Ju JC, Shin JH, Lee SJ, Cho HS, Sung NJ (2006) Antioxidative activity of hot water extracts from medicinal plants. J Kor Soc Food Sci Nutr 35: $7-14$

19. Folin O, Denis W (1912) On phoshotungstic-phosphomolybdic compounds as color reagents. J Biol Chem 12: 239-243

20. Blois MS (1958) Antioxidant determination by the use of stable free radical. Nature 181: 1199-1200

21. Stirpe F, della Corte E (1969) The regulation of rat liver xanthine oxidase. J Biol Chem 244: 3855-3863

22. Tibbot BK, Skadsen RW (1996) Molecular cloning and characterization of a gibberellin-inducible, putative á-glucosidase gene from barley. Plant
Mol Biol 30: 229-241

23. Dorfman A, Ott ML (1948) A turbidimetric method for the assay of hyaluronidase. J Biol Chem 172: 367-375

24. Wunsch E, Heidrich HG (1963) Zur quantitativen bestimmung der kollagenase. Hoppe-Seyler'eyle Physiol Chem 333: 149-151

25. Hearing VJ Jr (1987) Mammalian monophenol monooxygenase (tyrosinase): purification, properties, and reactions catalyzed. Methods Enzymol 142: 154-165

26. Lee JT, Jeong YS, An BJ (2002) Physiological activity of Salicornia herbacea and its application for cosmetic materials. Kor J Herb 17: 5160

27. Davidson PM, Parish ME (1989) Methods for testing the efficacy of food antimicrobials. Food Technol 43: 148-155

28. Choi HS, Kim MG, Shin JJ, Pack JM, Lee JS (2003) The antioxidant activities of the some commercial teas. J Kor Soc Food Sci Nutr 32: 723-727

29. Farag RS, Badei AZMA, Hewedi FM, El-Baroty GSA (1989) Antioxidant activity of some spice essential oils on linoleic acid oxidation in aqueous media. J Am Oil Chem Soc 66: 792-799

30. Frei B (1994) Natural antioxidants in human health and disease. Academic Press Publisher, p 40-55, Cambridge, Massachusetts, USA

31. Baker JF, Schumacher HR (2010) Update on gout and hyperuricemia. Int J Clin Pract 64: 371-377

32. Lee EH, Park HJ, Kim NH, Hong EJ, Park MJ, Lee SH, Kim MU, An BJ, Cho YJ (2016) Biological activities of Aster scaber extracts. Kor J Food Preserv 23: 393-401

33. Hanefeld M (1998) The role of acarbose in the treatment of non-insulindependent diabetes mellitus. J Diabetes Complications 12: 228-237

34. McDougall GJ, Stewart D (2005) The inhibitory effects of berry polyphenols on digestive enzymes. Bio Factors 23: 189-195

35. Ghosh P (1994) The role of hyaluronic acid in health and disease: interactions with cells, cartilage and components of synovial fluid. Clin Exp Rheumatol 12: 75-82

36. Giacomoni PU, Rein G (2001) Factors of skin ageing share common mechanism. Biogerontol 2: 219-229

37. No JK, Soung DY, Kim YJ, Shim KH, Jun YS, Rhee SH, Yokozawa T, Chung HY (1999) Inhibition of tyrosinase by green tea components. Life Sci 65: PL241-246

38. Hamilton AJ, Gomez BL (2002) Melanins in fungal pathogens. J Med Microbiol 51: 189-191

39. Tsuji N, Moriwaki S, Suzuki Y, Takema Y, Imokawa G (2001) The role of elastases secreted by fibroblast in wrinkle formation: implication through selective inhibition of elastase activity. Photochem Photobiol 74: 283-290 